\title{
The effect of temperature and composition to the rheological properties of asphalt pavements
}

\author{
László A. Gömze ${ }^{1, a}$, Róbert Géber ${ }^{2, b}$, Judit Csányi Tamásné ${ }^{3, c}$ \\ ${ }^{1,2}$ University of Miskolc, Department of Ceramics and Silicates Engineering, Hungary \\ ${ }^{3}$ EPCOS SZ IN RF PD, Hungary \\ afemgomze@uni-miskolc.hu, bfemgeber@uni-miskolc.hu, cjudit.csanyi@epcos.com
}

Keywords: rheology, ceramics, concretes, asphalt, asphalt-mixture, deformation

\begin{abstract}
Ceramics, concretes and asphalt-mixtures are the most popular building materials in Hungary, because of the highway programme of the government. In spite of their large popularity, some of the mechanical properties of ceramics, concretes and asphalts are not investigated enough till today. Particularly, there is no mechanical model usable to understand and explain the rheological behaviours of these materials with different compositions of mineral raw materials.

It is well known, that the viscosity of viscous materials, viscoelastic materials, and viscoplastic materials dynamically decreases, as the temperature increases. The decrease of viscosity by leaps and bounds could be extremely dangerous in case of asphalt pavements in the range of $55-75^{\circ} \mathrm{C}$, due to the crossing of cars on the low viscosity pavements which suffer inelastic deformation, as a result.

Using a Rheo-tribometer instrument developed by L. A. Gömze and others, the authors have investigated and tested asphalt mixtures with different composition of mineral raw materials, and would like to reveal and review the dependence of the rheological properties of these pavements against the temperature, and the intensity of the dependence.
\end{abstract}

\section{Introduction}

The modelling and examination of the rheological properties of ceramics and glasses was started in Hungary in 1952 [1]; some years later, than the books of the famous professors of the University of Chemical Technology Moscow, Bulavin [2] and Kitayagorodskij [3], were published discussing the topic in detail.

The testing methods and the fundamentals of rheological modelling $[4,5,6]$ of asphalt mixtures were also taken over from a Russian scientist, Gezencvej [7] in the middle of the 1960's.

The research on rheology and the mechanical modelling of complex, non-linear plastic-viscoelastic materials is continuing at the Department of Ceramics and Silicates Engineering (University of Miskolc) since, a 30 years collaboration of the associates of the world-famous University of Civil Engineering Moscow [8, 9, 10, 11], and also leaning on our own situations and opportunities [12, $13,14,15]$.

The growing research activity is well reflected by several domestic and international publications $[16,17,18,19]$, out of which a considerable part deals with the rheological properties of asphalt mixtures, or the reomechanical processes and deformations, which are caused by exterior mechanical forces acting on the asphalt $[20,21,22,23]$.

Pavement is an artificial material, which is layed by rolling, and it is based on a combination of bitumen, stone-powder and ballast stone. According to Gezencvej [7] asphalt - as structural building materials - is known as viscous material, and the Burgers rheological model was used to describe its behaviour. In these days is also used the Burgers model in asphalt rheology, but in 2005 a new rheological model for asphalt was created by the associates of the Department of Ceramics and Silicate Engineering, which describes effectively and precisely the physical and mechanical processes in asphalt concretes and in asphalt mixtures made with bitumen [21, 22, 25]. These models are depicted on Fig. 1. 


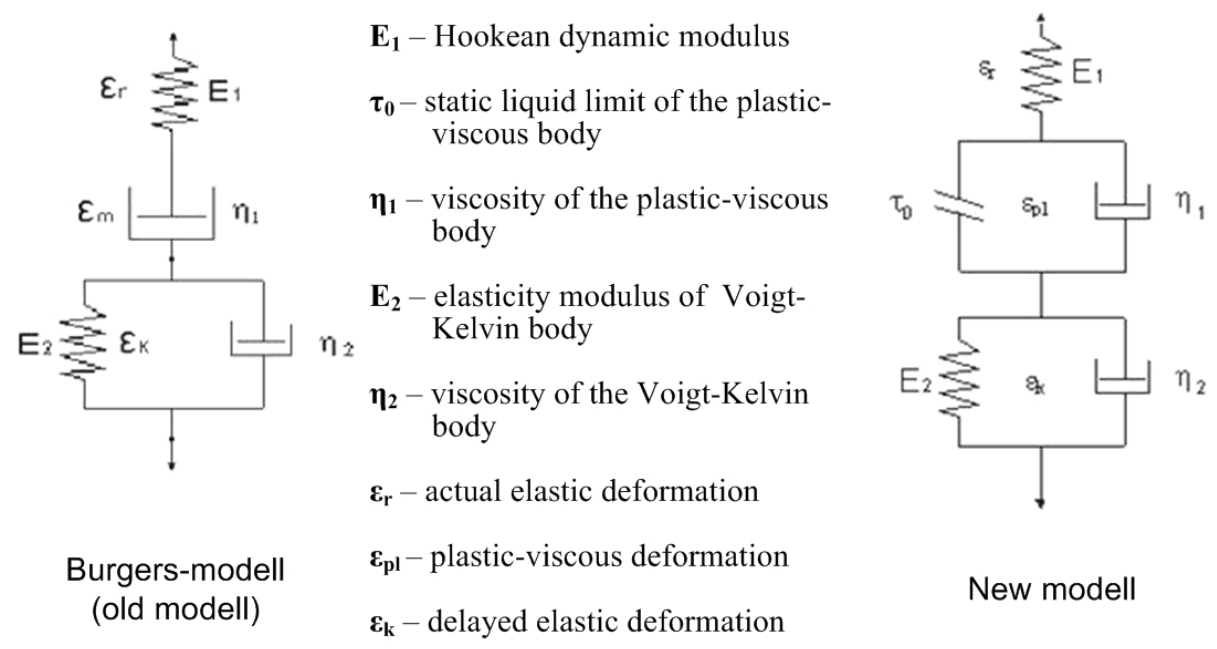

Fig. 1.

The (old) Burgers rheological model [26] and the new rheological model of asphalts and asphalt mixtures made with bitumen

The rheological equation [27] for asphalt mixtures and asphalt concretes with different composition, which also contains factors whole non-distorted and distorted material structures, was described by the following equation (1):

$$
\tau(t)=\tau_{0}+\eta_{1} \dot{\varepsilon}+\eta_{1} t_{r} \ddot{\varepsilon}-\dot{\tau}\left[t_{f r}-t_{r}\left(1-\frac{\eta_{1}}{\eta_{2}}\right)\right]-t_{r} t_{f r} \ddot{\tau} ;[\mathrm{MPa}]
$$

where: $\dot{\varepsilon}$ - first derivative by time of deformation of the material system;

$\ddot{\varepsilon}$ - second derivative by time of deformation of the material system;

$\tau_{0}-$ static liquid limit of the material system; [MPa]

$\dot{\tau}$ - first derivative by time of shear stress;

$\ddot{\tau}$ - second derivative by time of shear stress;

$\mathrm{t}_{\mathrm{r}}$ - delay time of elastic deformation; [s]

$\mathrm{t}_{\mathrm{fr}}$ - tension-relaxation time of the material system; [s]

The effective viscosity can be defined from Eq. 1. as follow:

$$
\eta_{e}=\frac{\tau_{0}+\eta_{1} \dot{\varepsilon}+\eta_{1} t_{r} \ddot{\varepsilon}}{\dot{\varepsilon}+t_{f r}+t_{r} \dddot{\varepsilon}+\ddot{\varepsilon}\left[t_{f r}+t_{r}\left(1+\frac{\eta_{1}}{\eta_{2}}\right)\right]} ;[\text { MPas }]
$$

\section{Deformations of asphalt mixtures}

Asphalts and asphalt concretes can behave in two ways in case of different shearing forces [25]:

- The material can suffer elastic deformation, if the amount of tension is lower, than the liquid limit of the material. This deformation is actual and non-permanent, so the material regains its original shape (Fig. 2.a).

- The material suffers plastic deformation, if the amount of stress is higher, than the liquid limit of the material. This deformation is non-elastic, the material will stay deformed (Fig. 2.b). 


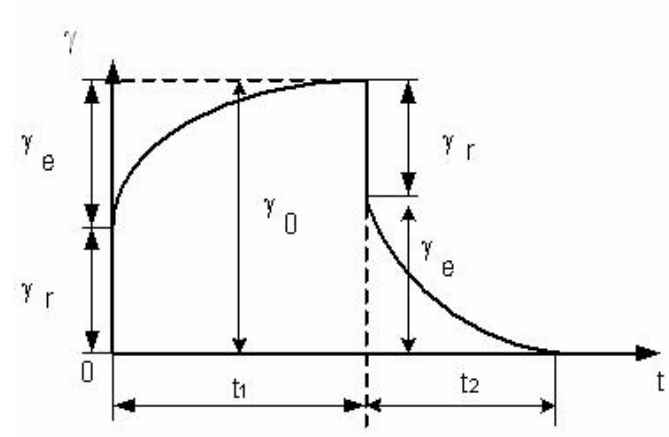

A specific deformation-time function in case of liquid limit is higher than tensions

$\tau<\tau_{0}$

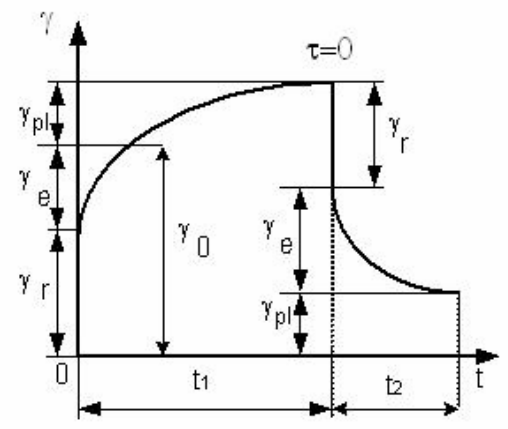

A specific deformation-time function in case of liquid limit Is lower than tensions

$\tau>\tau_{0}$

Fig. 2.a and 2.b.

where:

Deformation-time functions for different tensions [25]

$\mathrm{t}_{1}$ - duration of loaded state

$\mathrm{t}_{2}$ - duration of unloaded state

„e" and , r" indexes - elastic and plastic deformations

For the deformation-time functions, which are demonstrated on Fig. 2, it is possible to define the rheological parameters (Fig. 1.) for asphalt mixtures with different compositions.

\section{Shear tests of asphalt mixtures}

A Combined Rheo-tribometer instrument was successfully developed and patented by the coworkers of the Department of Ceramics and Silicate Engineering at the University of Miskolc [24] (Fig. 3.a)

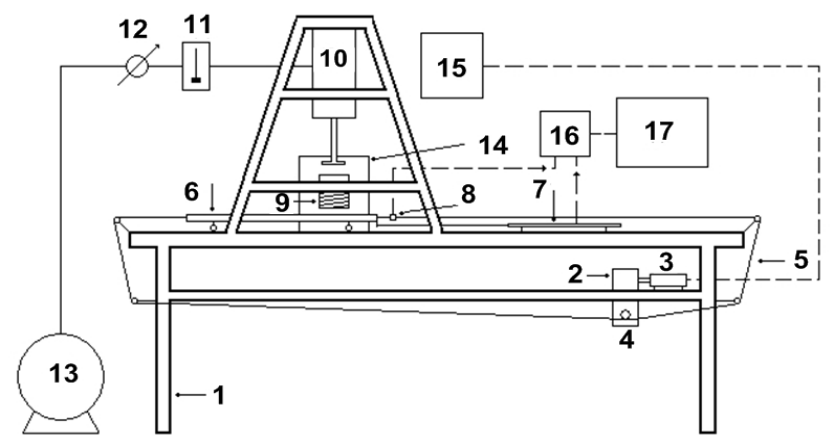

1. instrument table; 2 . snail drive; 3 . electric motor; 4. cable drum; 5. cableway; 6 . batching car (with the shearing plate);

7. inductive displacement detector; 8. force-meter (spider);

9. heatable specimen holder; 10. pneumatic power cylinder;

11. magnetic valve; 12. pressure gauge; 13. compressor; 14. thermostat; 15. control unit; 16. data recorder (Spider 8); 17. computer (capturing and processing data)

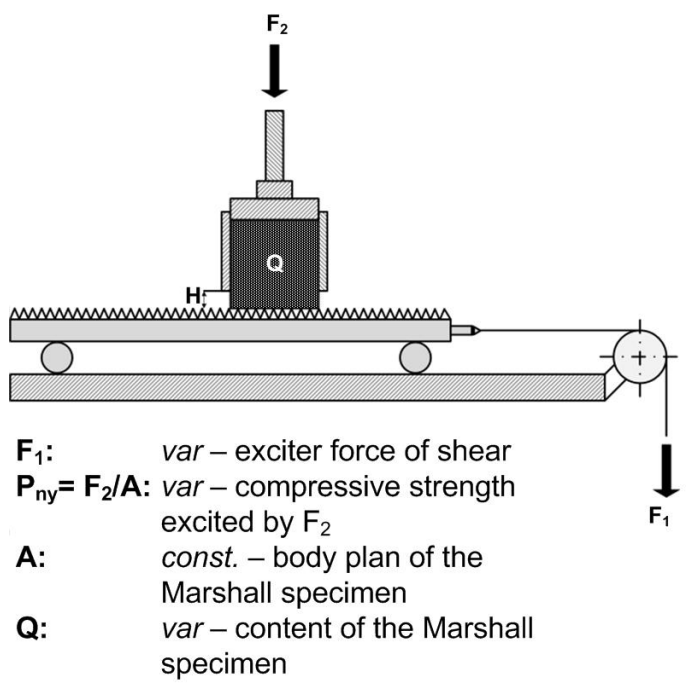

Fig. 3.a and 3.b.

The Rheo-tribometer instrument [24]

The Combined Rheo-tribometer instrument (Fig. 3.a) has a temperature controlled specimen holder (9) and a control unit with frequency changer (15). With these instrument it is possible to measure the mechanical stresses of asphalt mixtures during shearing. These mechanical stress $(\tau)$ can be characterized by the loading pressure $(p)$, content $(Q)$, temperature $(T)$, and shear ratio $(v)$ using the following equation (3.): computer (17). Effective viscosity $\left(\eta_{e}\right)$ of the tested specimens can be define by the distance $(H)$ 
between the shearing plate $(6)$ and specimen holder $(9)$, and shear ratio (v) with the following (4.) equation:

$$
\eta_{e}=\frac{\tau \cdot H}{v} ; \quad[\mathrm{MPas}]
$$

It is easy to measure the deformation-time curves, from the data recorded by the Combined Rheotribometer instrument; the actual $\left(\mathrm{E}_{1}\right)$, and delayed $\left(\mathrm{E}_{2}\right)$ elastic modulus, the plastic viscosity of destorted $\left(\eta_{1}\right)$ and non-destorted $\left(\eta_{2}\right)$ whole material structure and a static liquid limit of the tested material as function of the parameters; temperature, pressure, material composition and shear rate.

$$
\begin{aligned}
& \mathrm{E}_{1}=\mathrm{f}(\mathrm{p}, \mathrm{Q}, \mathrm{T}, \mathrm{v}) ;[\mathrm{MPa}] \\
& \mathrm{E}_{2}=\mathrm{f}(\mathrm{p}, \mathrm{Q}, \mathrm{T}, \mathrm{v}) ;[\mathrm{MPa}] \\
& \eta_{1}=\mathrm{f}(\mathrm{p}, \mathrm{Q}, \mathrm{T}, \mathrm{v}) ;[\mathrm{MPa}] \\
& \eta_{2}=\mathrm{f}(\mathrm{p}, \mathrm{Q}, \mathrm{T}, \mathrm{v}) ;[\mathrm{MPa}] \\
& \tau_{0}=\mathrm{f}(\mathrm{p}, \mathrm{Q}, \mathrm{T}, \mathrm{v}) ;[\mathrm{MPa}]
\end{aligned}
$$

During the shear tests, standard Marshall-specimens [25] were tested with the Rheo-tribometer instrument (Fig. 3.). The specimens contained quartz sand (Fehérvárcsurgó), limestone-powder (Tatabánya) - as filler - in 3 different grain sizes $(0,09 \mathrm{~mm}-0,063 \mathrm{~mm}-0,032 \mathrm{~mm})$, and bitumen (Százhalombatta, type B50/70). Marshall-specimens were made of 3 different bitumen content $(2,9 \%, 3,4 \%$ and $3,9 \%)$. Testing temperatures were $50{ }^{\circ} \mathrm{C}$ and $80{ }^{\circ} \mathrm{C}$, the loading pressure was 1 bar. The following typical characteristic curves could be prepared from the recorded data (Fig. 4.):
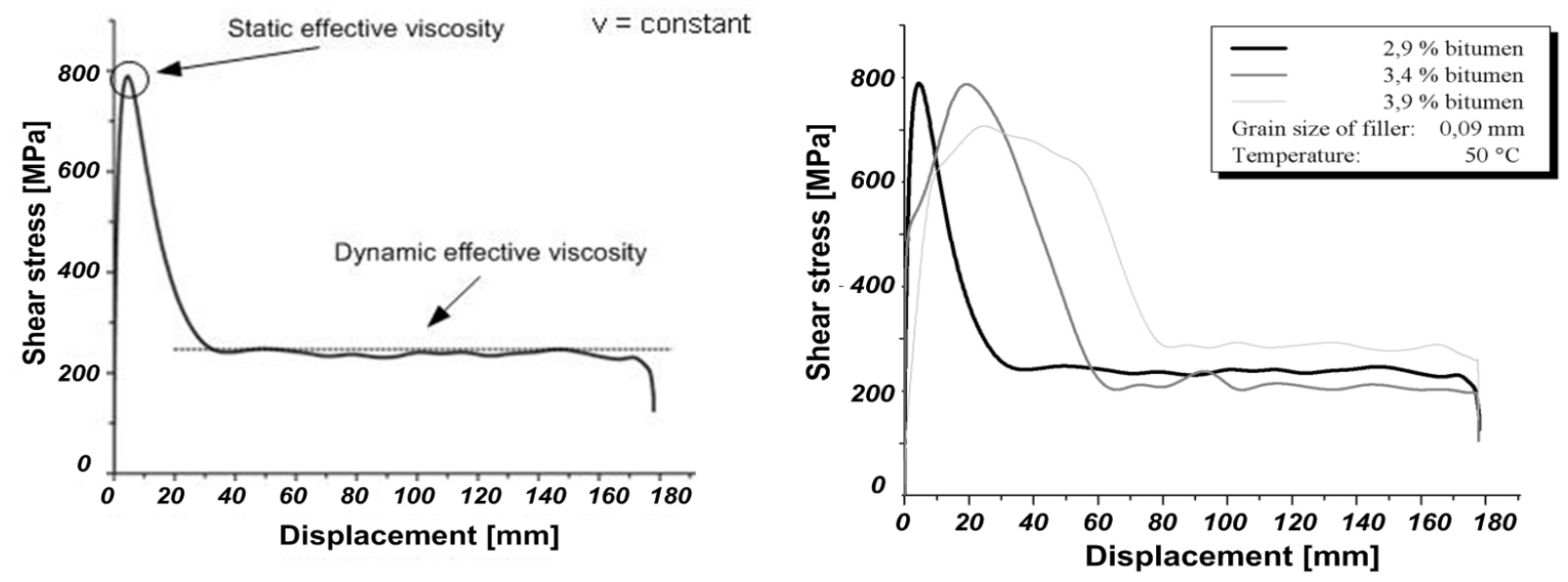

Fig. 4.a and 4.b

Typical displacement-shear stress diagrams of asphalt mixtures

There is a maximum shear stress value on the diagram. This maximum stress is necessary shearing stress for the deformation to begin. It is called the static effective viscosity $\left(\eta_{e}\right)$. This rheological parameter describes the main properties of the material, like actual elasticity modulus, elasticity modulus, the plastic viscosity of destorted material structure, and the viscosity of non-destorted of whole material structure. After the destruction of the material structure it is still necessary to sustain shearing. To sustain the shearing even a lower shear stress is enough, which is described by the dynamic effective viscosity $\left(\eta_{d}\right)$ (Fig. 4.).

\section{Results}

Table 1. shows the results of the shear tests. It contains the tested rheological parameters, the shearing stress necessary to start the shearing $\left(\tau_{\max }\right)$, the shearing stress required for sustaining the shearing $\left(\tau_{d}\right)$, static dynamic viscosity $\left(\eta_{d}\right)$ and static effective viscosity $\left(\eta_{e}\right)$. There were 10 measurements executed on every sample sets. Arithmetical mean values of the measurements are shown in Fig. 5., which shows the values of effective viscosity as a function of grain size at different bitumen content. 


\begin{tabular}{|c|c|c|c|c|c|c|c|c|c|c|}
\hline \\
\hline & & \multicolumn{9}{|c|}{ Grain size [mm] } \\
\hline & & \multicolumn{3}{|c|}{$0,09 \mathrm{~mm}$} & \multicolumn{3}{|c|}{$0,063 \mathrm{~mm}$} & \multicolumn{3}{|c|}{$0,032 \mathrm{~mm}$} \\
\hline & & \multicolumn{9}{|c|}{ Bitumen content [\%] } \\
\hline & Temperature $\left[{ }^{\circ} \mathrm{C}\right]$ & $2,9 \%$ & $3,4 \%$ & $3,9 \%$ & $2,9 \%$ & $3,4 \%$ & $3,9 \%$ & $2,9 \%$ & $3,4 \%$ & $3,9 \%$ \\
\hline \multirow{2}{*}{$\begin{array}{c}\tau_{\max } \\
{[\mathbf{M P a}]}\end{array}$} & $50^{\circ} \mathrm{C}$ & 0,0997 & 0,0985 & 0,0881 & 0,0942 & 0,1034 & 0,0875 & 0,1022 & 0,0942 & 0,0906 \\
\hline & $80^{\circ} \mathrm{C}$ & 0,0532 & 0,0698 & 0,0532 & 0,0581 & 0,0532 & 0,0661 & 0,0655 & 0,0961 & 0,0783 \\
\hline \multirow{2}{*}{$\begin{array}{c}\tau_{d} \\
{[\mathbf{M P a}]}\end{array}$} & $50^{\circ} \mathrm{C}$ & 0,0206 & 0,0184 & 0,0256 & 0,0218 & 0,0290 & 0,0181 & 0,0233 & 0,0277 & 0,0253 \\
\hline & $80^{\circ} \mathrm{C}$ & 0,0184 & 0,0211 & 0,0101 & 0,0180 & 0,0151 & 0,0174 & 0,0196 & 0,0193 & 0,0128 \\
\hline \multirow{2}{*}{$\begin{array}{c}\boldsymbol{\eta}_{\mathbf{d}} \\
{[\mathbf{M P a s}]}\end{array}$} & $50^{\circ} \mathrm{C}$ & 0,0357 & 0,0427 & 0,0566 & 0,0500 & 0,0465 & 0,0413 & 0,0474 & 0,0598 & 0,0538 \\
\hline & $80^{\circ} \mathrm{C}$ & 0,0543 & 0,0525 & 0,0285 & 0,0602 & 0,0327 & 0,0455 & 0,0471 & 0,0437 & 0,0334 \\
\hline \multirow{2}{*}{$\begin{array}{c}\eta_{\mathrm{e}} \\
{[\text { MPas] }}\end{array}$} & $50^{\circ} \mathrm{C}$ & 0,1728 & 0,2283 & 0,1949 & 0,2160 & 0,1655 & 0,1994 & 0,2079 & 0,2038 & 0,1926 \\
\hline & $80^{\circ} \mathrm{C}$ & 0,1569 & 0,1736 & 0,1497 & 0,1948 & 0,1154 & 0,1730 & 0,1575 & 0,2175 & 0,2039 \\
\hline
\end{tabular}

Table 1. / The results of shear tests

The results shows that the necessary shearing stress for shearing, and viscosity of the specimens are decreasing by the increase of temperature. In case of $3,4 \%$ bitumen content, there are local maximum and local minimum values on the diagrams in all cases. The reason of this could be explained as an effect of the process, which comes off of the interface of the bitumen and the filler.

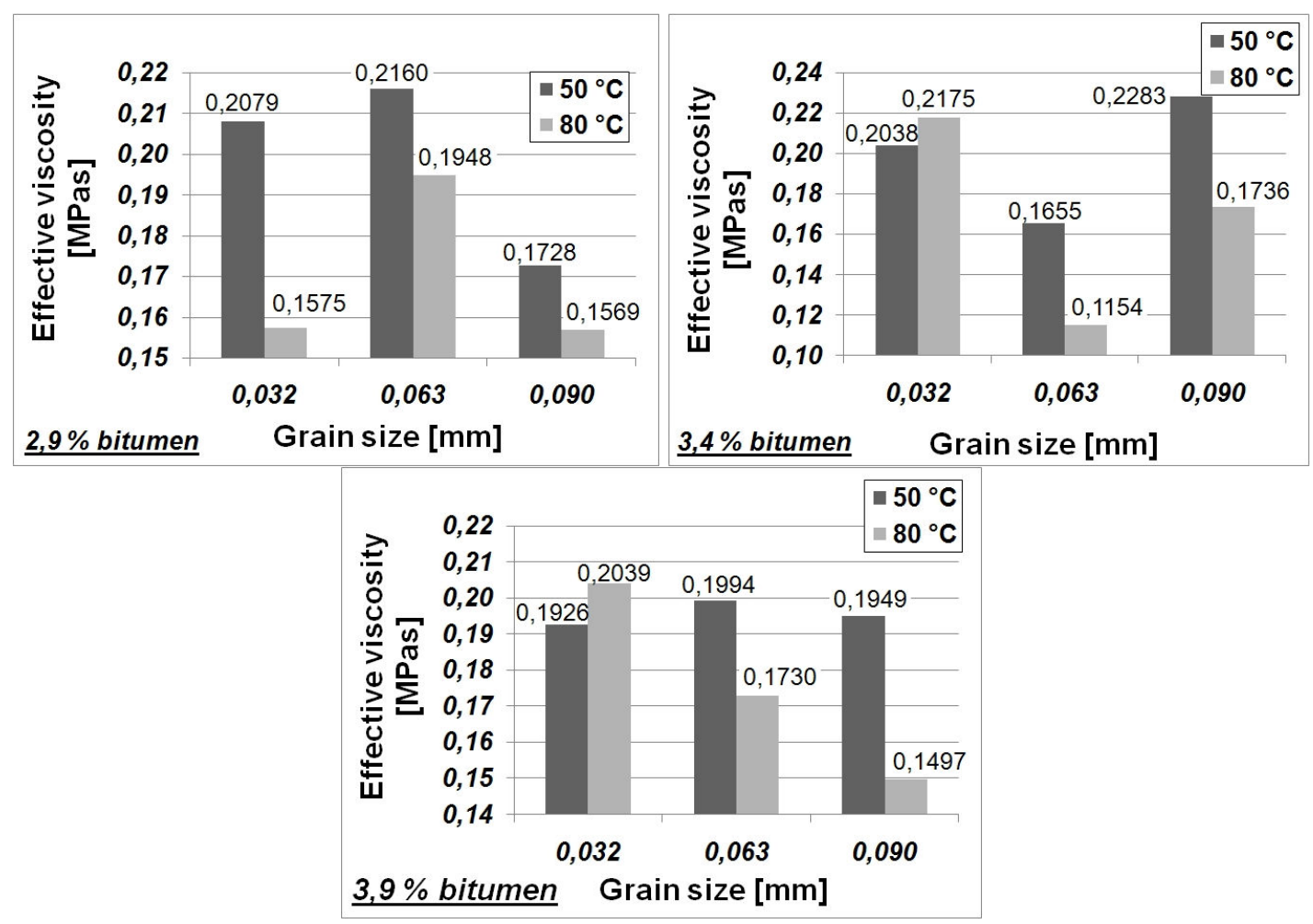

Fig. 5.

The amounts of effective viscosity as a function of grain size at different bitumen content

The effective viscosity of asphalt mixtures was investigated as a function of temperature earlier by the co-workers of the Department on standard Marshall samples [21, 22, 25]. The results show that the effective viscosity reduces by the increase of temperature (Fig. 6.). 


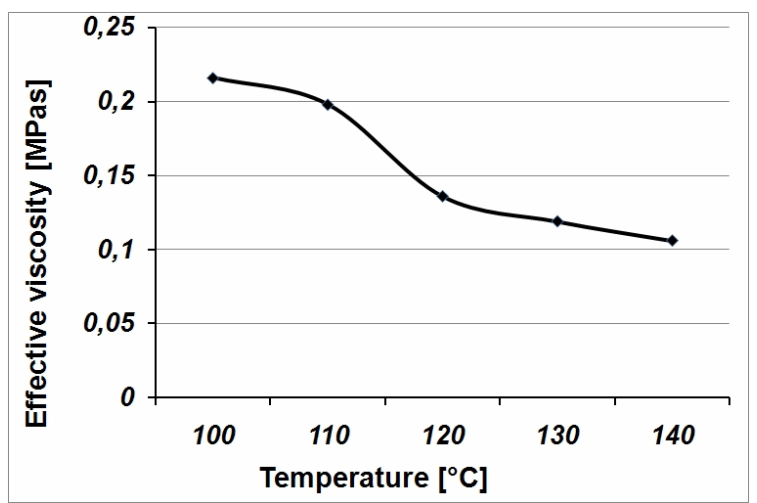

Fig. 6.

Effective viscosity of asphalt mixtures at different temperatures

\section{Results}

Using a Rheo-tribometer instrument developed and patented by L. A. Gömze and co-workers, the authors have investigated and tested standard Marshall specimens of asphalt mixtures with different composition varying the bitumen content and the grain size of mineral fillers. The authors executed their experiments at different temperatures, but at constant loading pressures, shear ratios and deformation speeds.

Previous investigations of the authors led to a new rheological model (shown above in Fig. 1.), and its mathematical description (1), which describes the real rheological properties of asphalt mixtures. According to the shear tests it is verified that the necessary shearing stress for shearing, and the viscosity of the specimens decrease by the increase of temperature. If the applied bitumen content is $3,4 \%$, there are local maximum and local minimum values on the diagrams in all cases. These differences could be explained as an effect of the process, which comes off of the interface of the bitumen and the filler. The decrease of grain size increases the specific surface of the filler, but there is no linear connection between the grain size and the rheological parameters. Previous laboratory tests also showed that viscosity decreases by the increase of temperature.

\section{References}

[1] F. Szalkay: Physical properties of glasses, Budapest (1952)

[2] Bulavin I. A.: Proizvodstvo keramicheskih plitok, Moskva, Promstrojizdat (1949)

[3] Kitayagorodszkij et. al.: Technologilya stekla, Strijzdta, Moskva (1951)

[4] J. Murali Krishnan - K.R. Rajagopal: On the mechanical behaviour of asphalt; Mechanics of Materials 37, pp. 1085-1100 (2005)

[5] J.P. Planche - P.M. Claudy - J.M. Létoffé - D. Martin: Using thermal analysis methods to better understand asphalt rheology; Thermochimica Acta 324, pp. 223-227 (1998)

[6] Y. Edwards - Y. Tasdemir - U. Isacsson: Rheological effects of commercial waxes and polyphosphoric acid in bitumen 160/220 - high and medium temperature performance; Construction and Building Materials 21, pp. 1899-1908 (2007)

[7] Gezencvej L. B.: Asphalt concrete pavements, KPM Proceedings, Budapest (1964)

[8] L. A. Gömze - Turenko A. V. - Nazarov V.: Mechanical modelling of comminution of plastic clays, Journal: Építőanyag, Vol. XXVI. 9. (1974)

[9] L. A. Gömze - Csirszkoj A. Sz. - Szilenok Sz. V. - Turenko A. V.: The rheology and flow relations of clay minerals comminuted by plain rolls, Journal: Építőanyag, Vol. XXXII. 12. (1981) 
[10]L. A. Gömze - Eller E. A.: Rheological investigation of extrudable asbestoscement bodies, Journal: Építőanyag, Vol. XXXV. 1. (1983)

[11]L. A. Gömze - Eller E. A.: Universal rotovisco for the rheological investigations of silicate industrial materials, SZILIKÁTTECHNIKA (1983)

[12]L. A. Gömze: Some theoretical question of glass rolling, considering the physical-mechanical properties of the processable glass composition, Manuscript, Nehézipari Müszaki Egyetem, Miskolc (1980)

[13]L. A. Gömze: The physical-mechanical properties of the comminuted clay minerals, as the factors influenced by dynamic load of plain rolls, BME Proceeding, Budapest (1980)

[14]L. A. Gömze: Some specific sizing problems of plain rolls used for the comminution of clay materials, Journal: Építőanyag, Vol. XXXII. 11. (1980)

[15]L. A. Gömze: Mathematical modeling of stress condition after pressure of asbestoscement products made by extruder, Journal: Építőanyag, Vol. XXXV. 5. (1983)

[16]A. Nagy: Rheologisches Verhalten von Microsilica, Miskolc (2000)

[17]I. Papp - L. A. Gömze - K. Olasz Kovács - A. Nagy: Anderung der Rheologischen Eigenschaften des Kaolins Al, Keramische Zeitschrift, v. 52. No. 9. (2000)

[18]I. Kocserha- L. A. Gömze: Examination of plastic light-clay masses, SZTE 20th Conference on Light-clay products, Proceeding (2002)

[19]I. Kocserha: Comparative examination of brick clays - the definition of external friction coefficient, MicroCAD Proceeding (2003)

[20]L. A. Gömze: Some actual questions of comminution theory -, comminution of plasticviscoelastic materials by chaser mill, Journal: Építőanyag, Vol. LV. 3. (2003)

[21]L. A. Gömze - Á. Kovács: Investigation of rheological properties of asphalt mixtures, Journal: Építőanyag, Vol. LVII. 2. (2005)

[22]L. A. Gömze - Á. Kovács: Investigation of rheological properties of asphalt mixtures, MicroCAD Proceeding, (2005)

[23]L. A. Gömze: Rheological modelling of ceramic materials and asphalt mixtures, $8^{\text {th }}$ Mining Metallurgy and Geology Conference, Proceeding, p.175-180 (2006)

[24]L. A. Gömze - I. Kocserha- Gy. Czél: Patented Invention No. U0200079, Hungarian patent Office, Budapest (2002)

[25]Á. Kovács.: Comparative examination of rheological and tribological properties of asphalt mixtures, Miskolc (2005)

[26] Gy. Mózes - E. Vámos: Rheology and rheometry, Budapest (1968)

[27]L. A. Gömze: Vibor osnovnih parametrov shnekovih pressov dlya formovaniyastroitel'nih izdelij iz asbestotzementnih mass, Avtoreferat, Moscow-1985 UDK 666033022

[28]T.Boucz: Laboratory excercises for road building, Budapest (1973) 